\title{
STRATEGI PEMASARAN UDANG VANNAMEI PADA TAMBAK UDANG PT. CENDANA PRIORITAS LESTARI KABUPATEN BENGKULU TENGAH
}

\author{
Tito Irwanto, Herry Novrianda, Dora Wasiati Ayu Juniarti \\ Program Studi Manajemen Fakultas Ekonomi Universitas Dehasen Bengkulu \\ tito.irwanto22@gmail.com
}

\begin{abstract}
ABSTRAK
Tito Irwanto, Herry Novrianda, Dora Wasiati Ayu Juniarti; Penelitian ini bertujuan untuk mengetahui kekuatan, kelemahan, peluang dan ancaman. Strategi yang paling tepat untuk tambak udang vannamei adalah mengunakan strategi SO, dengan menggunakan seluruh kekuatan untuk memanfaatkan peluang. Metode pengumpulan data menggunakan kuesioner dengan menyebarkan pertanyaan kepada responden. Hasil penelitian IFAS dan EFAS, maka kekuatan yang dimiliki pada PT. CendanaPrioritas Lestari Bengkulu Tengah adalah 19,94 sedangkan kelemahan adalah 5,7 jika kuadran internal faktor yaitu 19,94 - 5,7 = 14,24 peluang yang dimiliki dari strategi tersebut sebesar 17,08 untuk ancaman sehingga 10 jadi kuadran eksternal faktor yaitu 17,08 - $10=7,08$ sehingga berada pada kuadran 1 dalam analisis SWOT.
\end{abstract}

\section{ABSTRACT}

Tito Irwanto, Herry Novrianda, Dora Wasiati Ayu Juniarti; The purpose of this study is to know the strengths, weaknesses, opportunities and threats. The most appropriate strategy for vannamei shrimp farms is to use SO strategies, using all the power to exploit opportunities. Methods of data collection using questionnaires by spreading questions to respondents.

Result of research of IFAS and EFAS, hence power owned at PT. CendanaPrioritas Lestari Bengkulu Tengah is 19.94 while the weakness is 5.7 if the internal quadrant factor is $19.94-5.7=14.24$ the opportunity of the strategy is 17.08 for the threat so that 10 is the external quadrant factor $17,08-10=7.08$ so that it is in quadrant 1 in SWOT analysis.

Key Words: Marketing Strategy, SWOT Analysis.

\section{LATAR BELAKANG}

Pemasaran adalah kegiatan yang terpadu untuk mengembangkan rencana-rencana strategi yang diarahkan kepada usaha pemuasan kebutuhan serta keinginan pembeli atau konsumen, guna mendapatkan strategi pemasaran yang menghasilkan laba atau keuntungan. Pemasaran juga merupakan salah satu sumber pendapatan seseorang atau suatu perusahaan yang melakukan transaksi jual dan beli. Dalam suatu perusahaan apabila semakin besar penjualan maka akan semakin besar pula pendapatan yang diperoleh seseorang atau perusahaan tersebut. Tujuan pemasaran adalah mendatangkan keuntungan atau laba dari produk-produk atau jasa yang dihasilkan produsennya dengan pengelolaan yang baik dan juga mengharapkan keuntungan yang sebesar-besarnya. Akan tetapi hal ini perlu peningkatan kinerja dari pihak distributor dalam menjamin mutu dan kualitas barang ataupun jasa yang akan dijual.

Strategi pemasaran adalah proses penentuan rencana para pemimpin puncak yang berfokus pada tujuan jangka panjang organisasi, disertai penyusunan suatu cara atau upaya bagaimana agar tujuan tersebut dapat dicapai. Dalam artian khusus strategi pemasaran merupakan tindakan yang bersifat senantiasa meningkat dan terus menerus, serta dilakukan berdasarkan sudut pandang tentang apa yang diharapkan oleh para pelanggan di masa depan dan kegiatan dalam perekonomian yang berfungsi membantu menentukan nilai ekonomi dimana nilai ekonomi disini berupa harga barang dan jasa. Penentuan nilai harga barang dan jasa sangat dipengaruhi oleh tiga faktor kunci yaitu produksi, pemasaran dan konsumsi, oleh karena itu strategi pemasaran menjadi penghubung yang sangat kuat bagi perusahaan.

Strategi Pemasaran merupakan cara dimana pengusaha atau karyawan PT. Cendana Prioritas Lestaridalam memasarkan usahanya untuk meningkatkan volume penjualan dengan mempertimbangkan harga dan produk yang di tawarkan ke pembeli (konsumen). Faktor internal adalah faktor yang berasal dari dalam perusahaan seperti kekuatan dan kelemahan yang mana dalam hal ini dapat berpengaruh terhadap pemasaran Udang Vannamei Pada Tambak Udang PT. Cendana Prioritas Lestari, Kekuatan artinya keunggulan yang dimiliki Usaha Tambak Udang PT. Cendana Prioritas Lestari dalam 
persaingannya yang berkaitan dengan strategi pemasaran sepertimemiliki surat izin usaha,harga jual udang vannamaei yang standar harga jual pasaran, tersedianya saluran distribusiyang baik,pemesanan udang sudah sesuai dengan permintaan konsumen, memiliki sarana dan prasana yang ada. Kelemahan artinya keterbatasan yang dimiliki Usaha Tambak Udang PT. Cendana Prioritas Lestari dalam strategi pemasaran yang diterapkan sepertimasalah pengelolaan keuangan perusahaan, promosi produk yang tidak menggunakan media, dan kualitas pelayanannya yang masih kurang. Peluang adalah kesempatan dalam mengembangkan usahanya untuk mendapatkan penghasilan bagi perusahaan untuk memperoleh seperti hubungan perusahaan dengan konsumen terjalin dengan baik, peminat udang vannamei besar dipasaran, masyarakat dapat berkerja di perusahaan, udang yang dijual sesuai standar penjualan udang, dan hubungan baikprusahaan dengan pemasok benur. Ancaman adalah adanya masalah yang mengakibatkan tidak adanya keuntungan dan menjadikan tantangan bagi pengusaha sepertiadanya persaingan penjualan udang vannamei, pemesanan konsumen dalam waktu cepatyang tidak selalu terpenuhi, berkurangnya kepercayaan konsumen dengan perusahaan, adanya isu-isu yang tidak baik terhadap perusahaan, perkembangan benur yang telah ditebar dalam kolam.

Analisis SWOT (strengths, weaknesses, opportunities and threats) adalah suatu teknik yang dirancang khusus untuk membantu mengidentifikasi strategi pemasaran yang harus dijalankan perusahaan. Analisis SWOT mencakup lingkungan internal dan eksternal perusahaan. Analisis SWOT dapat mengarahkan proses pembuatan rencana strategi pemasaran yang baik. Analisis SWOT dapat bermanfaat dalam menemukan keunggulan strategi pemasaran yang dapat dieksploitasi dalam strategi pemasaran perusahaan.Mengembangkan strategi pemasaran yang berhasil memerlukan kegiatankegiatan yang berbeda dari pesaing, Perusahaan harus memiliki misi perusahaan. Misi ini menjadi dasar untuk membuat perencanaan strategi pemasaran yang diawali dengan melakukan analisis SWOT. Analisis SWOT membentuk struktur informasi internal dan eksternal kedalam empat kategori yaitu kekuatan dan kelemahan (internal) serta peluang dan ancaman (eksternal).

Tambak udang adalah sebuah kolam yang dibangun untuk membudidayakan udang, baik udang air tawar, air payau, maupun air asin. Udang merupakan salah satu jenis hewan penyaring sehingga kualitas air (keasaman dan kadar garam) sangat menentukan hasil yang didapatkan oleh petambak.Udang yang potensial untuk dibudidayakan dalam tambak adalah udang vaname, dan mampu menoleransi kadar garam antara 0 hingga 45 persen.

PT. Cendana Prioritas Lestari merupakan salah satu perusahaan yang membudidayakan udang vannamei. Hasil produksinya dijual kepada pelanggan tetap seperti rumah makan, restoran yang berada di kota Bengkulu,perusahaan distributor yang berada diluar kota Bengkulu, dan kepada konsumen seperti masyarakat di lingkungan setempat. Secara administratif perusahaan ini terletak di Desa Pondok Kelapa, Kabupaten Bengkulu Tengah, Provinsi Bengkulu.

Udang vannamei memiliki nilai ekonomis terbesar, pernyataan ini didukung oleh petani yang telah kami jumpai di lokasi. Petani lebih suka membudidayakan vannamei karena panen yang lebih cepat dan lebih menguntungkan. Menurut Fariyanto (2012:126) di Indonesia, dalam dekade terakhir ini budidaya udang dikembangkan secara mantap dalam rangka menanggapi permintaan pasar udang dunia. Pengembangan budidaya udang vannamei semakin pesat menggantikan budidaya udang lainnya, alasan utama beralihnya pembudidayaan udang lain ke udang vannamei antara lain adalah laju pertumbuhan udang vannamei yang cepat serta kerentanan yang rendah terhadap penyakit. Hal ini ditunjukkan mulai menurunnya produksi industri budidaya udang lainnya akibat patogen viral yang menyerang udang, produksi udang kemudian meningkat lagi dengan pesat setelah di budidayakannya udang vannamei.

\section{LANDASAN TEORI}

\section{Pasar dan Pemasaran}

Pasar merupakan suatu tempat di mana para penjual dan pembeli dapat bertemu untuk melakukan jual beli barang. Penjual menawarkan barang dagangannya dengan harap dapat laku terjual dan memperoleh uang sebagai gantinya. Disana penjual dan pembeli akan melakukan tawar - menawar harga hingga terjadi kesepakatan harga. Setelah kesepakatan harga dapat dilakukan, barang akan berpindah dari tangan penjual ke tangan pembeli. Pembeli akan menerima barang dan penjual akan menerima uang. Hal ini merupakan pengertian pasar secara konkrit, artinya pengertian pasar dalam kehidupan seharihari, yaitu tempat orang-orang bertemu untuk melakukan suatu transaksi jual beli barang. Namun pasar juga dapat diartikan dalam pengertian pasar menurut ilmu ekonomi (abstrak). Di pasar antara penjual dan pembeli akan melakukan transaksi. Transaksi adalah kesepakatan dalam kegiatan jual-beli. Syarat terjadinya transaksi adalah ada barang yang diperjual belikan, ada pedagang, ada pembeli, ada kesepakatan harga barang, dan tidak ada paksaan dari pihak manapun. 
Menurut Kotler (2008:201), pengertian pasar merupakan seperangkat pembeli aktual dan juga potensial dari suatu produk atau jasa. Ukuran dari pasar itu sendiri tergantung dengan jumlah orang yang menunjukkan tentang kebutuhan, mempunyai kemampuan dalam bertransaksi. Banyak pemasar yang memandang bahwa penjual dan pembeli sebagai sebuah pasar, dimana penjual tersebut akan mengirimkan produk serta jasa yang mereka produksi dan juga guna menyampaikan atau mengkomunikasikan kepada pasar. Sebagai gantinya, mereka akan mendapatkan uang dan informasi dari pasar tersebut.

Pasar menurut Staton (2013:109) merupakan tempat dimana para pedagang (penjual) dan pembeli bertransaksi. Di sana mereka bisa menawar harga yang cukup miring ke timbang belanja di mallmall. Pasar menjadi salah satu tempat dimana orang-orang bisa menjual barang, jasa dan tenaga kerjanya dengan imbalan uang. Hal ini merupakan pengertian pasar secara konkrit, artinya pengertian pasar dalam kehidupan sehari-hari, yaitu tempat orang-orang bertemu untuk melakukan suatu transaksi jual beli barang.

Menurut Rangkuti (2015:224),kata pasar mempunyai3 pengertian, antara lain:

1. Pasar dalam arti tempat, merupakan sebuah tempat untuk bertemunyapara penjual dengan pembeli.

2. Pasar dalam arti penawaran serta permintaan,merupakan pasar sebagai tempat terjadinya kegiatan transaksi jual beli.

3. Pasar dalam arti sekumpulan anggota masyarakat yang mempunyai kebutuhan serta daya beli, lebih merujuk pada 2 hal, yaitu daya beli dan kebutuhan. Pasar merupakan sekumpulan orang yang berusaha untuk mendapatkan jasa atau barang serta mempunyai kemampuan untuk membeli barang tersebut.

Berdasarkan dari penjelasan diatas, dapat disimpulkan beberapa ciri - ciri pasar, antara lain :

a. Terdapat calon pembeli dan penjual.

b. Terdapat jasa ataupun barang yang hendak untuk diperjualbelikan.

c. Terdapat proses permintaan serta penawaran oleh kedua pihak.

d. Terdapat interaksi diantara pembeli dan penjual baik itu secara langsung ataupun tidak langsung. Menurut Rangkuti (2015:112) Jenis - Jenis Pasar dibedakan bentuk kegiatan, cara transaksi dan menurut jenis barangnya sebagai berikut:

1. Menurut dari bentuk kegiatannya pasar

a. Pasar nyata

Pasar nyata adalah pasar diman barang-barang yang akan diperjual belikan dan dapat dibeli oleh pembeli. Contoh pasar tradisional dan pasar swalayan.

b. Pasar abstrak

Pasar abstrak adalah pasar dimana para pedagangnya tidak menawar barang-barang yang akan dijual dan tidak membeli secara langsung tetapi hanya dengan menggunakan surat dagangannya saja. Contoh pasar online, pasar saham, pasar modal dan pasar valuta asing.Menurut cara transaksinya, jenis pasar dibedakan menjadi pasar tradisional dan pasar modern.

c. Pasar tradisional

Pasar tradisonal adalah pasar yang bersifat tradisional dimana para penjual dan pembeli dapat mengadakan tawar menawar secar langsung. Barang-barang yang diperjual belikan adalah barang yang berupa barang kebutuhan pokok.

d. Pasar modern

Pasar moderen adalah pasar yang bersifat modern dimana barang-barang diperjual belikan dengan harga pas dan denganm layanan sendiri. Tempat berlangsungnya pasar ini adalah di mal, plaza, dan tempat-tempat modern lainnya.

2. Pasar menurut struktur dibedakan menjadi empat macam yaitu pasar persaingan sempurna, monopoli, persaingan monopolistik, dan oligopoli.Pasar persaingan sempurna disebut juga pasar persaingan murni adalah pasar di mana terdapat banyak penjual dan pembeli dan mereka sudah sama-sama mengetahui keadaan pasar.

Pemasaran adalah kegiatan yang terpadu untuk mengmbangkan rencana-rencana strategi yang diarahkan kepada usaha pemuasan kebutuhan serta keinginan pembeli atau konsumen, guna mendapatkan strategi pemasaran yang menghasilkan laba atau keuntungan. Pemasaran juga merupakan salah satu sumber pendapatan seseorang atau suatu perusahaan yang melakukan transaksi jual dan beli. Dalam suatu perusahaan apabila semakin besar penjualan maka akan semakin besar pula pendapatan yang diperoleh seseorang atau perusahaan tersebut.

Pemasaran menurut Rangkuti (2015:101), adalah suatu proses kegiatan yang di pengaruhi oleh berbagai faktor sosial, budaya, politik, ekonomi, dan manejerial. Akibat dari pengaaruh berbagai faktor tersebut adalah masing-masing individu maupun kelompok mendapatkan kebutuhan dan keinginan dengan menciptakan, menawarkan, dan menukarkan produk yang memiliki nilai komoditas. Sedangkan 
pemasaran menurut Stanton (2013-169), mengemukakan pengertian pemasaran berati berkerja dengan pasar sasaran untuk mewujudkan pertukaran yang potensial dengan maksud memuaskan kebutuhan dan keinginan manusia. Sehingga dapat dikatakan bahwa keberhasilan pemasaran merupakan kunci dari suatu perusahaan.Dengan demikian dapat dijelaskan bahwa pemasaran merupakan usaha terpadu untuk menggabungkan rencana-rencana strategis yang diarahkan kepada usaha pemuas kebutuhan dan keinginan konsumen untuk memperoleh keuntungan yang diarapkan melalui proses pertukaran atau transaksi. Kegiatan pemasaran oleh perusahaan harus dapat memberikan kepuasan kepada konsumen bila ingin mendapatkan tanggapan baik dari konsumen.

Menurut Kotler (2008:231) unsur pokok dalam kegiatan pemasaran adalah sebagai berikut:

1. Pemasaran adalah organisasi perusahaan atau perorangan yang mempunyai tujuan tertentu bagi organisasi maupun pribadinya. Tujuan pemasar tersebut misalnya keuntungan, survive, pangsa pasar, kesetiaan pelanggan, kesejahteraan dan sebagainyayang harus dipenuhi. Pemasar mempunyai kapasitas (sumberdaya, tekhnologi, dan manajemen) teretntu yang mampu memprodusir barang dan jasa sebagai pemenuhan permintaan pasar. Kapsitas masing-masiing unsur dalam setiap organisasi atau pribadi belum tentu seimbang. Misalnya suatu perusahaan mempunyai sumber dana lebih rendah daripada tingkat tekhnologi yang dimilikiProdusen (umumnya berorientasi terhadap keuntungan)

2. Organisasi (belum tentu berorientasi terhadap keuntungan)

3. Pemerintah (berorientasi terhadap kesejahteraan umum)

4. Barang dan jasa merupakan bentuk sesuatu yang ditawarkan produsen perusahaan yang mempunyai kebutuhan dan keinginan yang terwujud sebagai permintaan terahdap barang atau jasa. Pada umumnya. Tujuan dari konsumen pribadi adalah pemenuhan dan kepuasan kebutuhan dan keinginannya. Sedang tujuan pasar organisasi perusahaan adalah keuntungan atau yang lain. Pasar mempunyai kapasitas pertukaran (daya beli) untuk bisa memperoleh barang yang dimint. Daya beli adalah kemampuan pasar untuk mendapatkan barang yang diperlukan, daya beli dapat berwujud penguasaan uang, barang yang bernilai untuk ditukarkan, ataupun kepercayaan orang lain bahwa mereka mampu membayar.

5. Peroses pertukaran adalah kegiatan dua pihak yang masing-masing memerlukan sesuatu milik pihak lain sebagai usaha untuk pemenuhan kebutuhan dan keinginan masing-masing. Pertukaran dapat dilakukan secara barter atau transaksi penjualan dengan syarat-syarat yang disepakati secara layak oleh kedua belah pihak. Artinya dalam pertukaran tersebut tidaklah ada pihak yang dirugikan. Bahkan kedua pihak merasa diuntungkan dengan adanya pertukaran tersebut (win-win agreement). Dengan demikian dalam setiap pertukaran selalu ada proses penciptaan nilai tambah pada masing-masing pihak.

\section{Strategi Pemasaran}

Strategi pemasaran adalah proses pengambilan keputusan tentang keadaan lingkungan yang diharapkan dan kondisi persaingan dan merupakan tindakan yang bersifat senantiasa meningkat dan terus menerus, serta dilakukan berdasarkan sudut pandang tentang apa yang diharapkan oleh para pelanggan di masa depan dan kegiatan dalam perekonomian yang berfungi membantu menentukan nilai ekonomi dimana nilai ekonomi disini berupa harga barang dan jasa. Penentuan nilai harga barang dan jasa sangat dipengaruhi oleh tiga faktor kunci yaitu produksi, pemasaran dan konsumsi, oleh karena itu strategi pemasaran menjadi penghubung yang sangat kuat bagi perusahaan.

Strategi pemasaran menurut David (2010:186) adalah proses penentuan rencana para pemimpin puncak yang berfokus pada tujuan jangka panjang organisasi. Disertai penyusunan suatu cara atau upaya bagaimana agar tujuan tersebut dapat dicapai. Dalam artian khusus strategi merupakan tindakan yang bersifat incremental (senantiasa meningkat) dan terus menerus, serta dilakukan berdasarkan sudut pandang tentang apa yang diharapkan oleh para pelanggan di masa depan.

Menurut Assauri (2008:188), Pemasaran adalah suatu kegiatan dalam perekonomian yang berfungi membantu menentukan nilai ekonomi dimana nilai ekonomi disini berupa harga barang dan jasa. Penentuan nilai harga barang dan jasa sangat dipengaruhi oleh tiga faktor kunci yaitu produksi, pemasaran dan konsumsi.

Menurut Kotler (2007:301), strategi Pemasaran adalah suatu proses sosial dan manajerial yang didalamnya individu dan kelompok mendapatkan apa yang mereka butuhkan dan inginkan dengan menciptakan, menawarkan, dan mempertukarkan produk yang bernilai kepada pihak lain.

Menurut David (2010:178)Tiga faktor utama yang menyebabkan terjadinya perubahan strategi dalam pemasaran yaitu : 
1. Daur hidup produk

Strategi harus disesuaikan dengan tahap-tahap daur hidup, yaitu tahap perkenalan, tahap pertumbuhan, tahap kedewasaan dan tahap kemunduran.

2. Posisi persaingan perusahaan di pasar

Strategi pemasaran harus disesuaikan dengan posisi perusahaan dalam persaingan, apakah memimpin, menantang, mengikuti atau hanya mengambil sebagian kecil dari pasar.

3. Situasi ekonomi

Strategi pemasaran harus disesuaikan dengan situasi ekonomi dan pandangan kedepan, apakah ekonomi berada dalam situasi makmur atau inflasi tinggi.

Menurut Assauri (2008:163), macam-macam strategi pemasaran dapat diklasifikasikan menjadi tiga macam sebagai berikut :

1. Strategi pemasaran tidak membeda-bedakan pasar atauundifferentiated marketing merupakan strategi pemasaran yang tidak membeda-bedakan konsumen berdasarkan suatu kriteria khusus artinya kebutuhan konsumen secara umum tanpa membeda-bedakan.

2. Strategi pemasaran membeda-bedakan pasar atau differntiated marketing adalah perusahaan melakukan pengklasifikasian berdasarkan suatu kriteria tertentu

3. Strategi pemasaran pasar terkonsentrasi atau concentrated marketing adalah perusahaan memfokuskan pemasaran produknya dalam beberapa kelompok konsumen dengan mempertimbangkan keterbatasan sumberdaya perusahaan.

Dalam pemasaran terdapat enam konsep yang merupakan dasar pelaksanaan kegiatan pemasaran suatu organisasi yaitu: Konsep Produk, Konsep Penjualan, Konsep Pemasaran, Konsep Pemasaran Sosial, dan Konsep Pemasaran Global.

a. Konsep Produk

Konsep produk mengatakan bahwa konsumen akan menyukai produk yang menawarkan mutu, performansi dan ciri-ciri yang terbaik. Tugas manajemen disini adalah membuat produk yang berkualitas karena konsumen dianggap menyukai produk berkualitas tinggi dalam penampilan dengan ciri-ciri terbaik.

b. Konsep Penjualan

Konsep penjualan berpendapat bahwa konsumen, dengan dibubarkan begitu jasa, organisasi harus melaksanakan upaya penjualan dan promosi yang agresif.

c. Konsep Pemasaran

Konsep pemasaran mengatakan bahwa kunci untuk mencapai tujuan organisasi terdiri dari penentuan kebutuhan dan kegiatan pasar sasaran serta memberikan kepuasan yang diharapkan secara lebih efektif dan efisien dibandingkan para pesaing

d. Konsep Pemasaran Sosial

Konsep pemasaran sosial berpendapat bahwa tugas organisasi adalah menentukan kebutuhan, keinginan, danm kepentingan pasar sasaran serta memberikan kepuasan yang diharapkan dengan cara yang lebih efektif dan efisien dari pada para pesaing dengan tetap melestarikan atau meningkatkan kesejahteraan konsumen dan masyarakat

e. Konsep Pemasaran Global

Pada konsep pemasaran global ini, menejer eksekutif berupaya memahami semua faktor-faktor lingkungan yang mempengaruhi pemasaran melalui manajemen strategi yang mantap. Tujuan akhirnya adalah berupaya untuk memenuhi keinginan semua pihak yang terlibat dalam perusahaan.

\section{Bauran Pemasaran (Marketing Mix)}

Bauran Pemasaran menurut Kotler adalah (2007:211) mendefinisikan bauran pemasaran sebagai seperangkat alat pemasaran yang digunakan perusahaan untuk tujuan pemasarannya dan pasar sasaran. Bauran pemasaran merupakan kumpulan strategi yangterdiri dari 4P yaitu produk (Product), harga (Price), saluran distribusi (Place), dan promosi (Promotion). Keempat bauran tersebut dijelaskan sebagai berikut:

1. Produk (product)

Merupakan penawaran yang nyata oleh perusahaan pada pasar, termasuk didalam kualitas produk, ciri atau desain, pilihan gaya, merk dagang, kemasan, ukuran, pelayanan, jaminan dan pengambilan. Permasalahan yang timbul disini adalah, produk yang paling diinginkan olehkonsumen. Untuk itu perusahaan harus berorientasi kepada kebutuhan dan keinginan konsumen, yaitu :

a. Menentukan produk dari pembeli yang akan dilayani

b. Memilih kelompok pembeli tertentu sebagai sasaran penjualan

c. Menetukan produk dan program pemasarannya 
d. Penelitian terhadap konsumen

e. Menentukan strategi yang paling baik untuk menghadapi produk sejenis.

2. Harga (price)

Harga adalah sejumlah uang yang harus dibayarkan pelanggan untuk memperoleh suatu produk yang konsumen butuhkan.

3. Saluran distribusi (place)

Saluran distribusi merupakan suatu tempat dimana kegiatan usaha yang membuat produk tersedia bagi pelanggan atau konsumen.

4. Promosi (promotion)

Promosi adalah suatu aktifitas yang menyampaikan manfaat produk untuk menunjang konsumen atau pelanggan dalam pembeliannya untuk memujuk pelanggan sasaran untuk membeli.

\section{Analisis SWOT}

Analisis SWOT (strengths-Weaknesses-Opportunies-Threats) merupakan cara untuk mengamati lingkungan pemasaran eksternal dan internal.SWOT adalah singkatan dari strengths (kekuatan), weaknesses (kelemahan), opportunities (peluang), dan threats (ancaman), dimana SWOT ini dijadikan sebagai suatu model dalam menganalisis suatu organisasi yang berorientasi profit dan non profit dengan tujuan utama untuk mengetahui keadaan organisasi tersebut secara lebih komprehensif.

Ada yang harus diingat bahwa analisis SWOT tidak hanya menarik untuk dikaji oleh para manajer atau para top management perusahaan, namun menjadi menarik juga jika dikaji secara pribadi. terutama untuk melihat potensi diri seseorang serta prospek yang akan diraih dalam pekerjaannya dimasa depan. Melakukan analisis SWOT artinya diajarkan untuk masuk dalam analisis diri secara komperensif, dengan begitu anda akan menjadi lebih mengenal diri serta pribadi yang dimiliki untuk lebih jauh menempatkan kajian secara strategis. Ini bagaimana ditegaskan oleh Stephen P. Robbins dan Mary Coulter bahwa, dengan meluangkan waktu untuk mengindetifikasi apa yang penting secara pribadi, anda dapat menyusun sebuah rencana strategi dan menjamin bahwa rencana itu dilaksanakan secara efektif hingga anda puas.

Untuk menganalisis secara lebih dalam tentang SWOT, maka perlu dilihat faktor eksternal dan internal sebagai bagian penting dalam analisis SWOT, yaitu:

a. Faktor Eksternal

Faktor eksternal ini mempengaruhi terbentuknya opportunities and threats ( $\mathrm{O}$ and $\mathrm{T})$. Dimana faktor ini menyangkut dengan kondisi-kondisi yang terjadi di luar perusahaan yang mempengaruhi dalam pembuatan keputusan perusahaan. Faktor ini mencakup lingkungan industri (industry environment) dan lingkungan bisnis makro (macro environment), ekonomi, politik, hukum, teknologi, kependudukan, dan sosial budaya.

b. Faktor Intenal

Faktor internal ini mempengaruhi terbentuknya strengths and weaknesses. Dimana faktor ini menyangkut dengan kondisi yang terjadi dalam perusahaan, yang mana ini turut mempengaruhi terbentuknya keputusan (decison making) perusahaan. Faktor internal ini meliputi semua macam manajemen fungsional: pemasaran, keuangan, operasi, sumberdaya manusia, penelitian dan pengembangan, sistem informasi manajemen, dan budaya perusahaan (corporate culture).

Dalam hal ini Putong (2013:264) mengatakan bahwa, berdasarkan nilai peringkat dan membobotan yang kemudian dikalikan akan diperoleh hasil kombinasi antara beberapa situasi sebagai berikut :

1. Kekuatan artinya perusahaan menentukan strategi berdasarkan kombinasi kekuatan dan kesempatan yang bisa memanfaatkan kekuatan untuk menggunakan peluang sebaik-baiknya.

2. Kelemahan artinya perusahaan harus membuat strategi bagaimana meminimalkan kelemahan yang selalu muncul dalam perusahaan dengan memanfaatkan peluang yang menguntungkan.

3. Peluang artinya perusahaan bisa memanfaatkan kekuatan baik dalam hal management, sistem pemasaran maupun kemampuan finansial untuk mengatasi ancaman atau situasi penting yang menguntungkan dalam lingkungan usaha.

4. Ancaman adalah keadaan yang tidak menguntungkan dalam lingkungan usaha. Ancaman merupakan penganggu utama bagi posisi sekarang atau yang diinginkan perusahaan misalnya masuknya pesaing baru merupakan ancaman bagi pengusaha.

5. Matriks SWOTdilakukan dengan cara memasukan seluruh poin strenght, wraknesses, opprotunities, dan threaths ke dalam matriks lalu membagikannya kedalam empat usaha dengan mengalokasikan hasil dari perkalian bobot dan ranting kedalam SO, WO, ST, dan WT yang merupakan kombinasidari semuakekuatan, kelemahan, peluang, dan ancaaman. Berdasarkan matriks SWOT diatas maka didapatkan 4 langkah strategi yaitu sebagai berikut : 
1. Strategi SO

Strategi ini dibuat untuk memanfaat seluruh kekuatan dan memanfaatkan peluang sebesarbesarnya berdasarkan jalan pikiran pengusaha.

2. Strategi ST

Strategi ini merupakan strategi untuk menggunakan kekuatan yang dimiliki perusahaan dalam mengatasi ancaman.

3. Strategi WO

Strategi ini memanfaatkan peluang yang ada dengan cara meminimalkan kelemahan yang ada.

4. Strategi WT

Strategi yang didasarkan pada kegiatan perusahaan yang bersifat denfensif dan berusaha meminimalkan kelemahan yang ada serta menghindari ancaman.

Menurut Irham Fahmi (2013:266), matrik analisis SWOT adalah cara untuk mengamati lingkungan pemasaran eksternal dan internal serta untuk menyusun faktor-faktor strategi usahnya. Matrik SWOT ini digambarkan bagaimana manajemen terhadap peluang-peluang dan ancaman eksternal yang akan dihadapi suatu usaha dengan kekuatan dan kelemahan internalnya.

\section{KERANGKA ANALISIS}

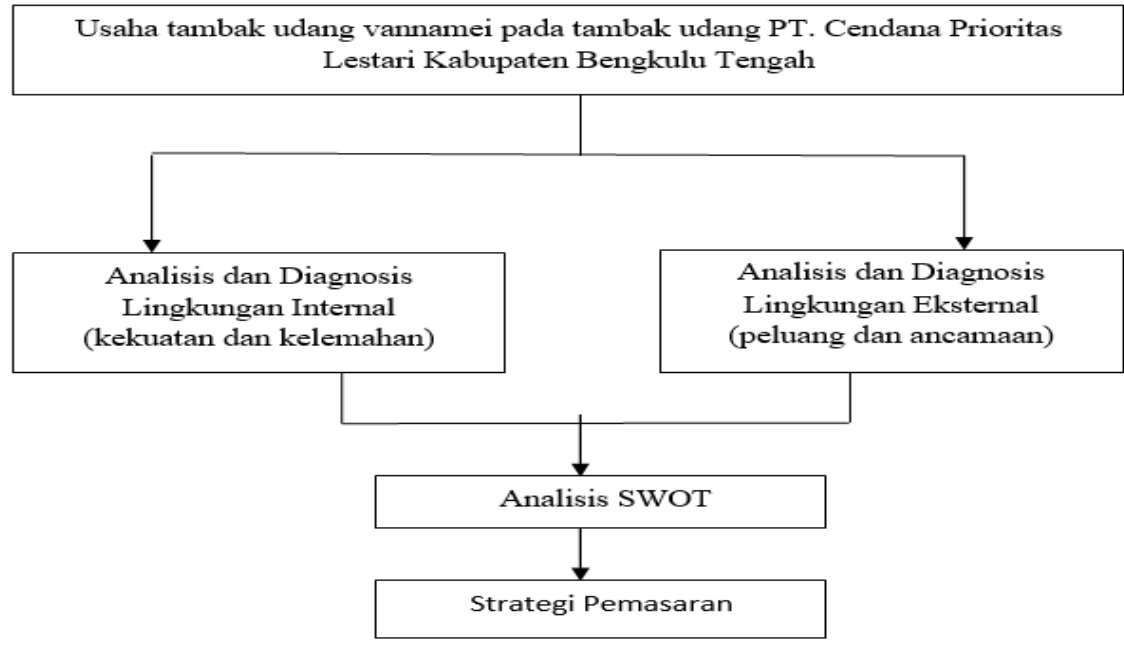

Gambar 1. Kerangka Analisis

\section{METODOLOGI}

Penelitian ini bertujuan menjelaskan strategi paling tepat yang bisa digunakan oleh perusahaan melalui penganalisisan kekuatan dan kelemahan, serta peluang dan ancaman yang di hadapi oleh Tambak Udang PT. Cendana Prioritas Lestari Kabupaten Bengkulu Tengah. Dalam penelitian ini populasi untuk faktor internal (IFAS) terdiri dari 8 orang karyawan Tambak Udang PT. Cendana Prioritas Lestari, populasi untuk faktor eksternal terdiri dari40 orang pelanggan, 20 orang konsumen, jadi total keseluruhan populasi sebanyak 68 orang.

Sampel adalah bagian dari jumlah dan karakteristik yang dimiliki oleh populasi. Dalam penelitian ini sampeluntuk faktor internal (IFAS) terdiri dari 4 orang karyawan Tambak Udang PT. Cendana Prioritas Lestari, sampel untuk faktor eksternal (EFAS)terdiri dari 20 orang pelanggan dan 10 orang konsumen.

\section{HASIL PENELITIAN DAN PEMBAHASAN}

\section{AnalisisSWOT untuk Strategi Pemasaran Udang Vannamei}

1. Analisis Faktor Internal

Dalam memasarkan udang vannamei maka sangat perlu menentukan strategi, dengan membuat analisis yang meliputi kekuatan (Strength) dan kelemahan (Weakness) yang dimiliki usahaTambak Udang PT. Cendana Prioritas Lestari Kabupaten Bengukulu Tengah. Dalam analisis ini disebut sebagai analisis SWOT yaitu sebagai berikut: 
Tabel 1. Faktor Analisis Strategi Internal (IFAS)

\begin{tabular}{|l|c|c|c|l|}
\hline Faktor-faktor Internal & Bobot & Rating & Skor & Komentar \\
\hline Kekuatan & & & & \\
1. Perusahaan sudah memiliki surat izin usaha & 0,93 & 4 & 3,72 & Kekuatan \\
2. Harga jual udang vannamaei terjangkau & 1,00 & 5 & 5,00 & Kekuatan \\
3. Saluran distribusinya strategis & 0,75 & 4 & 3,00 & Kekuatan \\
4. Udang yang dipesan sudah sesuai dengan & 1,00 & 5 & 5,00 & Kekuatan \\
$\quad$ permintaan konsumen & & & & \\
5. Sarana dan prasarana memadai & 0,81 & 4 & 3,24 & Kekuatan \\
\hline Jumlah & $\mathbf{4 , 4 9}$ & $\mathbf{2 2}$ & $\mathbf{1 9 , 9 7}$ & \\
\hline Kelemahan & & & & \\
1. Manajemen keungannya masih kurang stabil & 0,62 & 3 & 1,86 & Kelemahan \\
2. Promosi produk tidak menggunakan media & 0,43 & 2 & 0,86 & Bukan Kelemahan \\
3. Pelayanan masih kurang baik & 0,24 & 2 & 0,48 & Bukan Kelemahan \\
4. Tidak dapat memenuhi pemesanan udang & 0,68 & 3 & 2,04 & Kelemahan \\
$\quad$ dalam waktu cepat & & & & \\
5. Pemasaran produknya masih kurang baik & 0,23 & 2 & 0,46 & Bukan Kelemahan \\
\hline Jumlah & $\mathbf{2 , 2 0}$ & $\mathbf{1 2}$ & $\mathbf{5 , 7 0}$ & \\
\hline Total & $\mathbf{6 , 6 9}$ & $\mathbf{3 4}$ & $\mathbf{2 5 , 6 7}$ & \\
\hline
\end{tabular}

Sumber: Hasil Penelitian, 2017

a. Kekuatan (Strenght) yaitu :

1. Memiliki surat izin usaha

Tambak Udang PT. Cendana Prioritas Lestari Kabupaten Bengkulu Tengah ini sudah mendapatkan izin dari diknas setempat sehingga layak untuk di pasarkan dan dikonsumsi oleh konsumen.

2. Harga jual udang vannamaei terjangkau

Harga yang ditawarkanPada UsahaTambak Udang PT. Cendana Prioritas Lestari Kabupaten Bengkulu Tengah untuk penjualan udang dengan harga terjangkau tidak melebihi harga dipasaran sehingga tidak memberatkan konsumen dalam menjalin kerjasama dalam usaha mempromosikan udangnya.

3. Saluran distribusinya strategis

Usaha Tambak Udang PT. Cendana Prioritas Lestari Kabupaten Bengkulu Tengah terletak di Desa Pondok kelapa. Sedangkan areal pembenihan udang terletak di Sungai Hitam, Desa Pekik Nyaring. Kedua desa tersebut termasuk dalam Kecamatan Pondok Kelapa, Kabupaten Bengku Tengah, Provinsi Bengkulu. Secara ekologis, yang mana lokasi usaha ini letaknya strategis karena jalan tersebut merupakan salah satu jalan menuju luar kota bengkulu.

4. Pemesanan udang sudah sesuai dengan permintaan konsumen

Hasil udang yang dipanen cukup untuk memenuhi pemesanan konsumen dan sesuai dengan permintaan mereka.

5. Sarana dan prasarana yang ada

Sarana dan prasana yang diperlukan dalam pembudidayan udang vannamei sudah tersedia dengan baik sehingga membuat usaha menjadi lancar dan tanpa adanya kendala yang serius, seperti dalam pembudidayaan udang sudah memiliki bibit atau benur udang, makanan udang dan obat-obatan yang terbaik, dan dalam pengiriman hasil panen juga perusahaan sudah memiliki transportasi sendiri jadi tidak akan menghambat dalam pengiriman ke konsumen.

b. Kelemahan (Weakness) yaitu :

1. Keuangan di perusahaan

Pengelolaan keuangan Tambak Udang PT. Cendana Prioritas Lestari Kabupaten Bengkulu Tengahsudah cukup baik walaupun pengelolahannya mungkin masih mengalami kesulitan.

2. Promosi produk tidak menggunakan media

Perusahaan Tambak Udang PT. Cendana Prioritas Lestari tidak menggunakan media dalam memasarkan produk mereka dikarenakan mereka turun langsung kelapangan untuk menawarkan produk.

3. Pelayanan

Dalam memberi pelayanan masih kurang seperti terjadi kerusakan udang yang tidak semua tumbuh dengan baik dan sulit dikembalikan.

4. Pemesanan udang dalam waktu cepat 
Perusahaan tidak bisa memenuhi permintaan konsumen yang terlalu cepat dikarenakan udang vannamei memiliki siklus panen yang terdiri dari 6 bulan sekali panen, jadi tidak mungkin memenuhi permintaan konsumen dalam waktu sebulan sekali ataupun dua bulan sekali.

5. Pemasaran produk

Karena tidak menggunakan media dalam mempromosikan produknya maka perusahaan langsung memasarkan produknya ke konsumen dengan mendatangi konsumen dan membawa contoh udang yang mereka hasilkan dan memberikan beberapa argumen tentang udang vannamei yang perusahan mereka hasilkan, dan memberitahukan apa saja keunggulan dari produk perusahaan dibandingkan dengan udang vannamei yang dijualkan oleh perusahaan lain atau yang dijual dipasaran.

2. Analisis Faktor Eksternal

Dalam memasarkan udang vannamei maka sangat perlu menentukan strategi, dengan membuat analisis yang meliputi peluang (Opportunity) dan ancaman (Threats) yang dimiliki usahaTambak Udang PT. Cendana Prioritas Lestari Kabupaten Bengukulu Tengah. Dalam analisis ini disebut sebagai analisis SWOT yaitu sebagai berikut:

Tabel 2. Faktor Analisis Strategi Eksternal (EFAS)

\begin{tabular}{|c|c|c|c|c|}
\hline Faktor-faktor Eksternal & Bobot & Rating & Skor & Komentar \\
\hline Peluang & & & & \\
\hline 1. Hubungan baik perusahaan dengan konsumen & 0,95 & 4 & 3,80 & Peluang \\
\hline 2. Banyaknya peminat udang vannamei dipasaran & 0,91 & 4 & 3,64 & Peluang \\
\hline $\begin{array}{l}\text { 3. Masyarakat setempat dapat berkerja } \\
\text { diperusahaan }\end{array}$ & 0,75 & 4 & 3,00 & Peluang \\
\hline 4. Udang yang dijual sudah standar penjualan & 0,83 & 4 & 3,32 & Peluang \\
\hline $\begin{array}{l}\text { 5. Hubungan baik Perusahaan dengan pemasok } \\
\text { benur }\end{array}$ & 0,83 & 4 & 3,32 & Peluang \\
\hline Jumlah & 4,27 & 20 & 17,08 & \\
\hline Ancaman & & & & \\
\hline 1. Banyaknya persaingan penjualan udang vannamei & 0,79 & 4 & 3,16 & Ancaman \\
\hline 2. Pemesanan konsumen tidak selalu terpenuhi & 0,45 & 3 & 1,35 & Bukan Ancaman \\
\hline $\begin{array}{l}\text { 3. Berkurangnya kepercayaan konsumen dengan } \\
\text { perusahaan }\end{array}$ & 0,62 & 3 & 1,86 & Ancaman \\
\hline $\begin{array}{l}\text { 4. Adanya isu-isu yang tidak baik terhadap } \\
\text { perusahaan }\end{array}$ & 0,50 & 3 & 1,50 & Bukan Ancaman \\
\hline $\begin{array}{l}\text { 5. Benur yang ditebar tidak semua dapat } \\
\text { berkembang dengan baik }\end{array}$ & 0,58 & 3 & 1,74 & Ancaman \\
\hline Jumlah & 3,07 & 16 & 10,00 & \\
\hline Total & 6,71 & 33 & 21,7 & \\
\hline
\end{tabular}

Sumber: Hasil Penelitian, 2017

a. Peluang (Opportunity) yaitu :

1. Hubungan perusahaan dengan konsumen

Hubungan perusahaan dengan konsumen terjalin dengan baik dikarenakan perusahaan mengutamakan keunggulan produk mereka yang akan ditawarkan kepada konsumen.

2. Peminat udang vannamaei dipasaran

Dikarenakan udang vannamei udang yang memiliki rasa yang segar dan lezat jadi membuat peminat konsumen yang banyak, apalagi konsumen dari rumah makan, restoran dan perusahaan distributor yang bergerak dalam usaha kuliner udang, yang bahan pokok mereka adalah udang vannamei maka akan selalu memesan untuk memenuhi perminataan konsumen mereka.

3. Masyarakat dapat berkerja di perusahaan

Masyarakat yang tinggal didaerah dimana Tambak Udang PT. Cendana Prioritas Lestari yang terletak di Desa Pondok Kelapa menjadi prioritas utama oleh perusahaan untuk menjadi karyawan seperti menjadi Feeder untuk mengumpan udang, karyawan kantor, security dan pengamanan luar.

4. Udang yang dijual standar

Udang yang dijual perusahaan sesuai dengan standar penjualan udang dipasaran, udang yang segar , sehat, dan tentunya udang yang dijual udang yang berkualitas baik bukan yang jelek.

5. Hubungan dengan pemasok benur

Hubungan baik dengan perusahaan pemasok benur bertujuan agar bibit yang dibutuhkan perusahaan dapat terpenuhi dan tidak akan kekurangan untuk kebutuhan perusahaan dalam penebaran benur atau bibit. 
b. Ancaman (Threats)yaitu :

1. Persaingan penjualan udang vannamaei

Banyaknya persaingan perusahaan dalam penjualan udang vannamei dikarenakan sekarang sudah banyak perusahaan yang bergerak dalam pembudidayaan udang vannamei dan mereka bisa saja mengambil alih konsumen dan pelanggan karena banyaknya peminat udnag vannamei dipasaran.

2. Pemesanan konsumen tidak selalu terpenuhi

Tidak semua orang bisa membeli udang di perusahaan, dikarenakan jumlah panen udang yang terbatas setiap panennya dan perusahaan akan memprioritaskan pembelian udang untuk pelanggan dan konsumen tetap..

3. Kepercayaan konsumen dengan perusahaan

Takutnya berkurang kepercayaan konsumen dengan perusahaan dikarenakan tidak semua permintaan konsumen dapat berjalan dengan baik, dan juga terkadang udang tidak semua bisa berkembang dengan baik saat dipanen.

4. Adanya isu yang tidak baik terhadap perusahaan

Adanya isu yang tidak baik terhadap perusahan seperti pencemaran sungai yang terletak dekat dengan kolam udang, dan banyaknya ikan disungai yang mati membuat masyarakat setempat berfikir kalau itu kesalahan dari perusahaan yang membuang limbah kesungai.

5. Perkembamgan benur yang sudah ditabur dalam kolam

Tidak semua benur yang ditebar didalam kolam dapat berkembang dengan baik dikarenakan adanya penyakit udang yang akan menyerang.

\section{Matriks SWOT}

Dari hasil analisis SWOT, maka dapat disusun tabel matriks SWOT yang terdiri dari empat strategi usaha yaitu SO, WO, ST dan WT. Masing-masing strategi memiliki karakteristik tersendiri dan hendaknya dalam implementasi strategi dilakukan secara bersama-sama dan saling mendukung satu sama lainnya.

Dari analisis matriks SWOT terciptalah beberapa alternatif strategi untuk Usaha Tambak Udang PT. Cendana Prioritas Lestari Kabupaten Bengkulu Tengah.Berikut ini merupakan hasil dari analisis SWOT yang mana menunjukan adanya pengaruh faktor kekuatan, kelemahan, peluang, dan ancaman yang terjadi pada Usaha Tambak Udang PT. Cendana Prioritas Lestari Kabupaten Bengkulu Tengah.

Tabel 3.Matriks SWOT Usaha Tambak Udang PT. Cendana Prioritas Lestari Kabupaten Bengkulu Tengah.

\begin{tabular}{|c|c|c|}
\hline IFAS & $\begin{array}{l}\text { Kekuatan/ Strenght (S) } \\
\text { 1. Perusahaan sudah memiliki surat } \\
\text { izin usaha } \\
\text { 2. Harga jual udang vannamaei } \\
\text { terjangkau } \\
\text { 3. Saluran distribusinya strategis } \\
\text { 4. Udang yang dipesan sudah sesuai } \\
\text { dengan permintaan konsumen } \\
\text { 5. Sarana dan prasarana memadai }\end{array}$ & $\begin{array}{l}\text { Kelemahan/ Weakness }(\mathbf{W}) \\
\text { 1. Manajemen keungannya } \\
\text { masih kurang stabil } \\
\text { 2. Tidak dapat memenuhi } \\
\text { pemesanan udang dalam } \\
\text { waktu cepat }\end{array}$ \\
\hline $\begin{array}{l}\text { Peluang/ Opportunity (0) } \\
\text { 1. Hubungan baik perusahaan } \\
\text { dengan konsumen } \\
\text { 2. Banyaknya peminat udang } \\
\text { vannamei dipasaran } \\
\text { 3. Masyarakat setempat dapat } \\
\text { berkerja diperusahaan } \\
\text { 4. Udang yang dijual sudah standar } \\
\text { penjualan } \\
\text { 5. Hubungan baik Perusahaan } \\
\text { dengan pemasok benur } \\
\end{array}$ & $\begin{array}{l}\text { Strategi SO } \\
\text { Yaitu dengan memanfaatkan seluruh } \\
\text { kekuatan untuk merebut dan } \\
\text { memanfatkan peluang sebesar- } \\
\text { besarnya yang bisa menarik minat } \\
\text { pelanggan atau konsumen. }\end{array}$ & $\begin{array}{l}\text { Strategi WO } \\
\text { Yaitu menerapkan fungsi } \\
\text { manajemen yang lebih baik } \\
\text { untuk meningkatkan kinerja } \\
\text { demi kemajuan usaha tambak } \\
\text { dan memuaskan pelanggan dan } \\
\text { konsumen tetap melalui } \\
\text { pemanenan udang dalam } \\
\text { jumlah yang banyak. }\end{array}$ \\
\hline $\begin{array}{l}\text { Ancaman/ Threats }(\mathbf{T}) \\
\text { 1. Banyaknya persaingan penjualan } \\
\text { udang vannamei } \\
\text { 2. Berkurangnya kepercayaan } \\
\text { konsumen dengan perusahaan } \\
\text { 3. Benur yang ditebar tidak semua } \\
\text { dapat berkembang dengan baik }\end{array}$ & $\begin{array}{l}\text { Strategi ST } \\
\text { Yaitu meningkatkan kualitas produk } \\
\text { dan pelayanan, memanfaatkan } \\
\text { lingkungan sebagai tempat utama } \\
\text { dalam mempromosikan usaha dan } \\
\text { menjaga kepercayaan masyarakat } \\
\text { terhadap produk yang dijual dengan } \\
\text { harga yang terjangkau. }\end{array}$ & $\begin{array}{l}\text { Strategi WT } \\
\text { langkah yang harus diambil } \\
\text { adalah menyediakan bibit atau } \\
\text { benur, menjagakepercayaan } \\
\text { masyarakat yang mulai } \\
\text { berkurang dan harga produk } \\
\text { yang terjangkau tanpa } \\
\text { mengurangi kualitas udang. }\end{array}$ \\
\hline
\end{tabular}

Sumber : Hasil Penelitian dan diolah, 2017 
4. Diagram Analisis SWOT (Strenght, Weakness, Opportunity, Threats)

Dari analisi diatas maka dapat dibuat rekapitulasi dari perhitungan untuk melihat beberapa besar kekuatan, kelemahan, peluang, dan ancaman yang terjadi padaUsaha Tambak Udang PT. Cendana Prioritas Lestari Kabupaten Bengkulu Tengah.

Berdasarkan hasil perhitungan IFAS dan EFAS dapat dibuat rekapitulasi skor kekuatan, kelemahan, peluang dan ancaman yang dimiliki Usaha Tambak Udang PT. Cendana Prioritas Lestari Kabupaten Bengkulu Tengahberikut ini:

Tabel 4. Rekapitulasi Skor IFAS dan EFAS

\begin{tabular}{|l|l|l|l|l|}
\hline \multirow{2}{*}{} & IFAS & EFAS & Ancaman \\
\cline { 2 - 5 } & Kekuatan & Kelemahan & Peluang & 17,08 \\
\hline Strategi pemasaran & 19,94 & 5,7 & $17,08-10=7,08$ \\
\hline Kuadran & $19,94-5,7=14,24$ & \multicolumn{2}{l|}{10} \\
\hline
\end{tabular}

Sumber :Tabel 8, 9 dan diolah, 2017

Tabel 4. diatas menjelaskan strategi pada Usaha Tambak Udang PT. Cendana Prioritas Lestari Kabupaten Bengkulu Tengah.Yang mana hasil dari penjumlahan maka kekuatan (strength) yang dimiliki Usaha Tambak Udang PT. Cendana Prioritas Lestari Kabupaten Bengkulu Tengah adalah sebesar 19,94 sedangkan kelemahan (weaknesses) adalah sebesar 5,7 maka sel internal faktor usaha tersebut adalah 19,94 - 5,7 = 14,24 dan peluang (oppourtunities) yang dimiliki strategi tersebut adalah sebesar 17,08 dan untuk ancaman (threats) adalah sebesar 10 maka sel eksternal faktor tersebut adalah 17,08 - $10=7,08$ sehingga berada pada sel I dalam sel diagram analisis SWOT.

Berdasarkan hasil perhitungan tabel diatas maka titik temu internal faktor dengan eksternal faktor dapat digambarkan pada diagram analisis SWOT yang mana dapat menunjukan sel apakah titik temu ini berada. Hasil ini dapat dilihat dari diagram SWOT berikut ini:

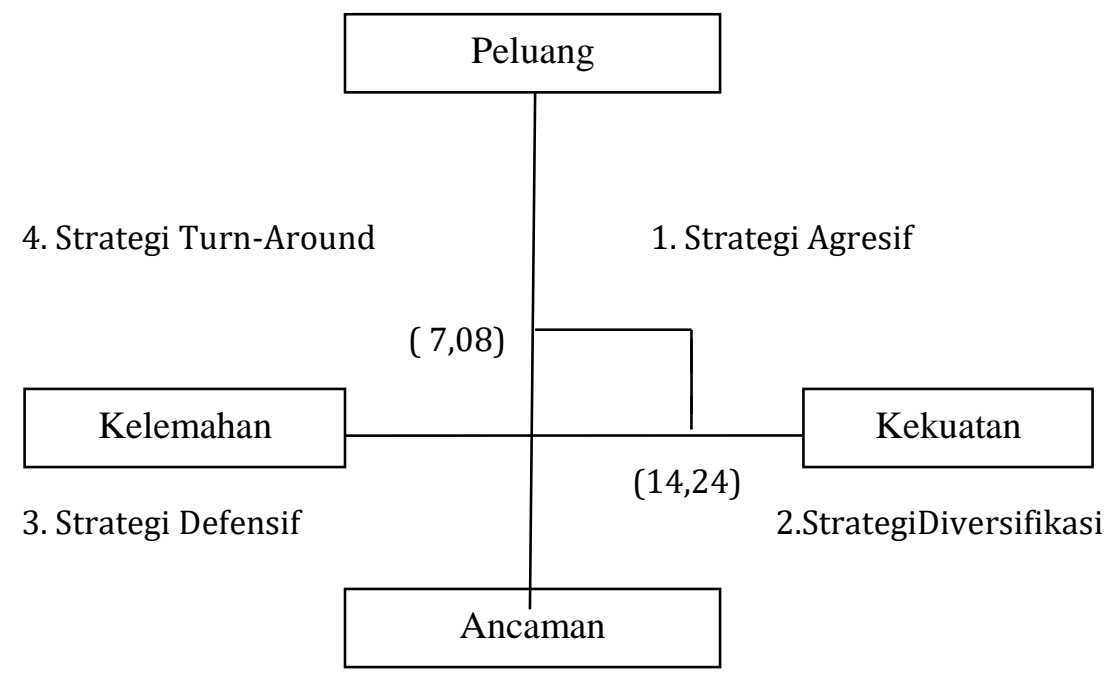

Gambar 4. Diagram Analisis SWOT Pada Usaha Tambak Udang PT. Cendana Prioritas Lestari Kabupaten

Sumber : data diolah, 2017

Bengkulu Tengah.

Keterangan:

Diagram Analisis SWOT diatas didapatkan dari hasil Tabel 12 Rekapitulasi Skor IFAS dan EFAS, dimana table tersebut terdapat hasil dari penjumlahan kekuatan (strength) yang dimiliki Usaha Tambak Udang PT. Cendana Prioritas Lestari Kabupaten Bengkulu Tengah adalah sebesar 19,94 sedangkan kelemahan (weaknesses) adalah sebesar 5,7 maka sel internal faktor usaha tersebut adalah 19,94 - 5,7= 14,24 dan peluang (oppourtunities) yang dimiliki strategi tersebut adalah sebesar 17,08 dan untuk ancaman (threats) adalah sebesar 10 maka sel eksternal faktor tersebut adalah 17,08 - 10=7,08 sehingga berada pada sel I dalam sel diagram analisis SWOT. Maka dapat disimpulkan letak Perusahaan Tambak Udang PT. Cendana Prioritas Lestari berada diantara Strategi Agresif kekutan dan peluang, diletakkan di kekuatan karena jumlah kekuatan lebih besar dibandingkan kelemahan, dan diletakkan di 
peluang karena jumlah peluang lebih besar dibandingkan Ancaman. Strategi Agresif menggambarkan posisi strategi usaha pada Usaha Tambak Udang berdasarkan diagram analisi SWOT yang menjelaskan tentang faktor eksternal dan faktor internal berada dalam sel (kuadran) I menunjukkan strategi SO dalam matriks SWOT yaitu mendukung strategi agresif. Strategi ini menerangkan bahwa strategi yang sangat menguntungkan bagi usaha karena memiliki peluang dan kekuatan dalam kemajuan usaha khususnya Usaha Tambak Udang PT. Cendana Prioritas Lestari Kabupaten Bengkulu Tengah.

\section{Pembahasan}

Berdasarkan hasil penelitian yang telah dilakukan pada Usaha Tambak Udang PT. Cendana Prioritas Lestari Kabupaten Bengkulu Tengahdi Kota Bengkulu dapat diartikan bahwa pendapat responden terhadap kekuatan (strenght) menunjukan bahwa kelima pernyataan merupakan kekuatan, tapi di dalam lima kekuatan terdapat dua kekuatan yang lebih kuat yaitu pada pernyataan dua dan empat dengan pernyataan harga udang vannamaei dengan skor 5,00 dan pemesanan udang sudah sesuai dengan permintaan konsumen dengan skor 5,00.Pendapat responden terhadap kelemahan menunjukan kelima pernyataan terdapat dua kelemahan yaitu pada pernyataan satu dan empat dengan pernyataan dengan keuangan diperusahaan dengan skor 1,86 dantidak dapat memenuhi pemesanan udang dalam waktu cepat dengan skor 2,04. Pendapat responden terhadap peluang menunjukan kelima pernyataan merupakan peluang dan terdapat dua pernyataan lebih kuat yaitu pada pernyataan satu dan empat dengan pernyataan hubungan baik perusahaan dengan konsumen dengan skor 3,8 dan udang yang dijual standar penjualan dengan skor 3,32. Pendapat responden terhadap ancaman menunjukan bahwa lima pernyataan terdapat tiga ancaman yaitu pada satu pernyataan dengan persaingan penjualan udang vannamaei dengan skor 3,16. Dari hasil IFAS dan EFAS maka kekuatan yang dimiliki Tambak Udang PT. Cendana Prioritas Lestari Kabupaten Bengkulu Tengahkekuatan sebesar 19,94 sedangkan kelemahan sebesar 5,7 jadi sel (kuadran) internal faktor yaitu 19,94 - 5,7 =14,24 sedangkan peluang yang dimiliki strategi tersebut sebesar 17,08 dengan ancaman 10 jadi Sel (kuadran) eksternal faktor yaitu 17,08 - $10=$ 7,08 yang berada pada Sel (kuadran) 1 pada diagram analisis SWOT. Dalam usaha ini menunjukan bahwa strategi pemasarannya adalah strategi agresif dengan menggunakan seluruh kekuatan dalam memanfaatkan peluang. Strategi ini dibuktikan berdasarkan usaha yang ada, yaitu dengan menggunakan seluruh kekuatan dalam memanfaatkan peluang. Strategi ini adalah strategi yang menguntungkan karena usaha tersebut memiliki peluang dan kekuatan dalam memajukan Tambak Udang PT. Cendana Prioritas Lestari Kabupaten Bengkulu Tengah.Matriks SWOT dilakukan dengan memasukkan seluruh point Strengh, Weakness, Opportunity dan Threats ke dalam matriks lalu membagikannya dalam empat usaha dengan mengalokasikan hasil dari perkalian bobot dan rating kedalam strategi SO, WO, ST, dan WT yang merupakan kombinasi dari semua kekuatan, kelemahan, peluang dan ancaman yang dihadapiUsaha Tambak Udang PT. Cendana Prioritas Lestari Kabupaten Bengkulu Tengah.

\section{KESIMPULAN}

1. Tambak Udang PT. Cendana Prioritas Lestari Kabupaten Bengkulu Tengahmemiliki kekuatan antara perusahaan sudah memiliki surat izin usaha, harga jual udang vannamaei yang terjangkau, sarana dan perasarana yang ada.

2. Tambak Udang PT. Cendana Prioritas Lestari Kabupaten Bengkulu Tengahmemiliki kelemahan yaitu tidak menggunakan media dalam memasarkan produknya, dan pemasaran dalam promosi usaha produk masih kurang.

3. Tambak Udang PT. Cendana Prioritas Lestari Kabupaten Bengkulu Tengahmemiliki peluang paling kuat yaitu pada hubungan baik perusahan dengan konsumen dan udang yang dijual standar penjualan.

4. Tambak Udang PT. Cendana Prioritas Lestari Kabupaten Bengkulu Tengahmemiliki ancaman banyaknya persaingan penjualan udang vannamei, berkurangnya kepercayaan konsumen dengan perusahaan, dan benur yang ditebar tidak semua dapat berkembang dengan baik.

\section{SARAN}

1. Selalu menjaga hubungan baik antara produsen dengan konsumen.

2. Menjaga kualitas benur untuk menghasilkan udang yang berkualitas.

3. Memberikan pelayanan yang baik agar konsumen tetap berlangganan dengan jangka waktu yang lama.

4. Meningkatkan kerjasama dan melakukan perluasan jaringan serta promosi.

5. Dalam membangun usahanya hendaklah menerapkan strategi berdasarkan analisis SWOT. 
6. Mampu bersaing dalam mempromosikan udang tidak hanya di dalam Kota Bengkulu saja akan tetapi di luar Kota bengkulu maupun diluar negri

\section{DAFTAR PUSTAKA}

Alma, Buchari. 2010. Kewirausahaan. Alfabeta. Bandung

Assauri. 2008. Strategi Pemasaran. Erlangga. Jakarta

David, Fred R. 2010. Manajemen Strategi. Salemba Empat. Jakarta

Fahmi, Irham. 2011. Manajemen (Teori, Kasus, dan Solusi). Alfabeta. Bandung

Fahrianto. 2012. Pengertian Usaha Tambak Udang. Edisi Kedua Jilid 1. Jakarta: Indonesia

Irham Fahmi. 2013. Matrik SWOT. Bandung: Alfabeta

Kotler, Philip. 2007. Manajemen Pemasaran. Jilid I. upper Saddle River.new Jersey

Prisca Wellianty. 2002. Strategi Pemasaran Untuk Meningkatkan Volume Penjualan.Skripsi tidak diterbitkan.Bengkulu. Fakultas Ekonomi Universitas Bengkulu.

Putong. 2013. Teknik Membeda Kasus Bisnis.Jakarta: PT Gramedia Pustaka Utama

Rangkuti. 2015. Strategi pemasaran.Salemba Empat. Jakarta

Santanto. 2013. Strategi pemasaran. Bandung: Alfabeta

Solihin, Ismail. 2009. Pengantar Manajemen. Erlangga. Jakarta

Subyakto. 2008. Pengertian udang. Edisi Kedua Jilid 2. Jakarta: Indonesia

Sugiyono. 2010. Metodologi Penelitian Bisnis. Jakarta. Alfabeta

Syahreza Yumanda. 2009. Strategi Pemasaran Kursi Kayu Jati. Skripsi tidak diterbitkan.Bengkulu.Fakultas Pertanian Universitas Sumatera Utara Medan. 